\title{
PELAKSANAAN DIVERSI OLEH PENYIDIK ANAK DALAM PENYELESAIAN TINDAK PIDANA NARKOTIKA DI POLRES BANJARNEGARA \\ (Studi Tentang Efektifitas Hukum)
}

\section{Oleh: AHMAD NUR HIDAYAT \\ Email : nurhidayatahmad@yahoo.co.id}

\begin{abstract}
Cases of abuse of narcotics in Banjarnegara district police in 2015 amounted to 6 (six) cases. Of the six (6) of this case, five (5) cases involving adult offenders resolved to go to court while one (1) case involving the abuse of drugs being resolved by mediation penal through diversion.
\end{abstract}

Keywords: Diversion, penal mediation, narcotic abuse

\section{Abstrak}

Perkara penyalahgunaan narkotika di Polres Banjarnegara tahun 2015 berjumlah 6 (enam) perkara. Dari 6 (enam) perkara ini, 5 (lima) perkara yang melibatkan pelaku dewasa diselesaikan sampai ke pengadilan sedangkan 1 (satu) perkara penyalahgunaan narkotika yang melibatkan anak diselesaikan dengan mediasi penal melalui diversi.

Kata kunci : Diversi, Mediasi penal, penyalahgunaan narkotika

\section{A. Pendahuluan.}

Anak merupakan bagian warga negara yang harus di lindungi karena mereka merupakan generasi bangsa yang dimasa yang akan datang melanjutkan kepemimpinan bangsa Indonesia. Setiap anak disamping wajib mendapatkan pendidikan formal seperti sekolah, juga wajib mendapatkan pendidikan moral sehingga mereka dapat tumbuh menjadi sosok yang berguna bagi bangsa dan negara. ${ }^{1}$

$$
\text { Penyalahgunaan narkotika, }
$$

psikotropika dan zat aditif merupakan kejahatan tanpa korban, dimana sebenarnya yang menjadi korban adalah pelaku itu sendiri. Oleh karena itu terhadap anak yang melakukan

1 https://www.mahkamahagung.go.id// Keadilan Restoratif Sebagai Tujuan Pelaksanaan Diversi Pada Sistem Peradilan Pidana Anak, Ridwan Mansyur, diakses pada hari Senin, 27 September 2015. tindak pidana penyalahgunaan narkotika, psikotropika dan zat aditif seharusnya penegak hukum khususnya penyidik menyerahkan penyelesaian masalah tersebut diluar pengadilan dengan mediasi penal (Penal Mediation) ${ }^{2}$ dengan melibatkan orang tua atau pihak lain sebagaimana amanat dari Undang-Undang Nomor 11 Tahun 2012 tentang Sistem Peradilan Pidana Anak. Menurut Natangsa Subakti,
dalam proses perkara pidana fungsionaris penegakan hukum, yaitu Penasehat Hukum, Polisi, Jaksa dan Hakim cenderung bekerja secara terpola dengan memfokuskan perhatian pada perbuatan yang dilarang atau tindak pidana (crime, strafbaarfeit) serta pelaku

\footnotetext{
2 Barda Nawawi Arief, 2012, Mediasi Penal: Penyelesaian Perkara Pidana Di Luar Pengadilan, Pustaka Magister, Semarang, hal. 1.
} 
449 | J urnal Idea Hukum

Vol. 2 No. 2 Oktober 2016

Magister Hukum Fakultas Hukum Universitas J enderal Soedirman

tindak pidana (criminal, offender) namun mengabaikan korban tindak pidana (victim). ${ }^{3}$ Sebagaimana dikemukakan oleh Muladi, hal tersebut membawa konsekuensi logis yaitu keadilan yang dihasilkan melalui proses pidana lebih merefleksikan kepentingan negara versus kepentingan pelaku tindak pidana, namun tidak memperhatikan kepentingan dan rasa keadilan dari pihak korban. ${ }^{4}$ Oleh karena itu diperlukan suatu perlindungan hukum bagi anak yang melakukan tindak pidana penyalahgunaan narkotika, psikotropika dan zat aditif dengan jalan penyelesaian diluar pengadilan melalui media penal ( penal mediation $)^{5}$.

Penyelesaian diluar pengadilan melalui mediasi penal telah diatur dalam Undang-Undang Nomor 11 Tahun 2012 Tentang Sistem Peradilan Pidana Anak. Dalam Sistem Peradilan Pidana Anak wajib diupayakan diversi. Diversi adalah pengalihan penyelesaian perkara anak dari proses peradilan pidana ke proses di luar peradilan pidana. Diversi dilakukan dalam hal tindak pidana yang dilakukan diancam dengan pidana penjara di bawah 7 (tujuh) tahun dan bukan merupakan pengulangan tindak pidana. Adapun dalam Peraturan Mahkamah Agung Nomor 4 Tahun 2014 Tentang Pedoman Pelaksanaan Diversi dalam Sistem Peradilan Pidana Anak Pasal 3 menyebutkan bahwa Hakim

3 Natangsa Subakti, 2015, Peradilan Restoratif Dalam Bingkai Empiri, Teori dan Kebijakan, Genta Publising, Yogyakarta, hal 3.

Ibid.

5 Barda Nawawi Arief, loc.cit. anak wajib mengupayakan diversi dalam hal anak didakwa melakukan tindak pidana yang diancam dengan pidana penjara dibawah 7 (tujuh) tahun dan didakwa dengan tindak pidana yang diancam dengan pidana penjara 7 (tujuh) tahun atau lebih dalam bentuk surat dakwaan subsidaritas, alternative, kumulatif maupun kombinasi (gabungan).

Berdasarkan ketentuan Pasal 9 Undang-Undang Nomor 11 Tahun 2012 Tentang Sistem Peradilan Pidana Anak, proses diversi wajib memperhatikan kepentingan korban, kesejahteraan dan tanggung jawab anak, penghindaran stigma negatif, penghindaran pembalasan, keharmonisan masyarakat dan kepatutan, kesusilaan, dan ketertiban umum. Penyidik, Penuntut Umum, dan Hakim dalam melakukan diversi harus mempertimbangkan kategori tindak pidana, umur anak, hasil penelitian kemasyarakatan dari Bapas dan dukungan lingkungan keluarga dan masyarakat. Kesepakatan diversi harus mendapatkan persetujuan korban dan/atau keluarga anak korban serta kesediaan anak dan keluarganya, kecuali untuk tindak pidana yang berupa pelanggaran, tindak pidana ringan, tindak pidana tanpa korban atau nilai kerugian korban tidak lebih dari nilai upah minimum provinsi setempat.

Berdasarkan hal tersebut di atas dapat dilihat bahwa penyelesaian tindak pidana yang berupa pelanggaran, tindak pidana ringan, tindak pidana tanpa korban, atau nilai kerugian korban tidak 
lebih dari nilai upah minimum provinsi setempat dapat dilakukan oleh penyidik bersama pelaku dan/atau keluarganya, ini menunjukkan penyidik mempunyai kewenangan mutlak untuk menyelesaian perkara tindak pidana tanpa korban termasuk salah satunya terhadap perkara tindak pidana narkotika yang dilakukan oleh anak. Oleh karena tindak pidana narkotika merupakan tindak pidana baik ada korban maupun tanpa adanya korban.

Perkara penyalahgunaan narkotika di wilayah hukum Polres Banjarnegara tahun 2015 berjumlah 6 (enam) perkara. Dari 6 (enam) perkara ini, 5 (lima) perkara yang melibatkan pelaku dewasa diselesaikan sampai ke pengadilan $\begin{array}{llll}\text { sedangkan } 1 & \text { (satu) perkara }\end{array}$ penyalahgunaan narkotika yang melibatkan anak diselesaikan dengan mediasi penal melalui diversi. Kasus penyalahgunaan narkotika yang dilakukan oleh tersangka anak yang bernama DA dalam laporan kepolisian telah melanggar Primair Pasal 114 ayat (1) Subsidair Pasal 111 ayat (1) Lebih Subsidair Pasal 127 ayat (1) huruf a Undang-undang Nomor 35 Tahun 2009 tentang Narkotika, proses penyelesaian perkara tersebut telah dilakukan dengan proses diversi oleh penyidik pada tingkat pemeriksaan di Polres Banjarnegara yang menghasilkan kesepakatan diversi antara anak sebagai pelaku atau korban dan orang tua pelaku dengan dihadiri oleh Penyidik sebagai fasilitator, petugas Bapas, dan tokoh masyarakat.
Berdasarkan kasus di atas ternyata ancaman pidana dalam Pasal 114 ayat (1) adalah paling lama seumur hidup, Pasal 111 ayat (1) adalah 12 (dua belas) tahun dan Pasal 127 ayat (1) huruf a ancaman pidananya 4 (empat) tahun, apakah pelaksanaan diversi dapat ditempuh oleh penyidik. Perumusan Masalah.

Berdasarkan uraian yang telah dikemukakan pada latar belakang di atas, maka dapat dirumuskan permasalahan sebagai berikut :

1. Apa yang menjadi dasar pertimbangan diterapkannya diversi oleh Penyidik Anak dalam penyelesaian tindak pidana narkotika di Polres Banjarnegara

2. Bagaimana proses pelaksanaan diversi oleh Penyidik Anak dalam penyelesaian tindak pidana narkotika di Polres Banjarnegara ?

3. Hambatan-hambatan apa saja dalam pelaksanaan diversi oleh Penyidik Anak dalam penyelesaian tindak pidana narkotika di Polres Banjarnegara?

B. Metode Penelitian.

1 Metode : Metode pendekatan Pendekat yuridis sosiologis an

2 Tipe : Penelitian hukum Penelitian sosiologis atau empiris.

3 Lokasi : Polres Banjarnegara, Penelitian Kejaksaan Negeri Banjarnegara,Penga dilan Negeri 
451 | J urnal Idea Hukum

Vol. 2 No. 2 Oktober 2016

Magister Hukum Fakultas Hukum Universitas J enderal Soedirman

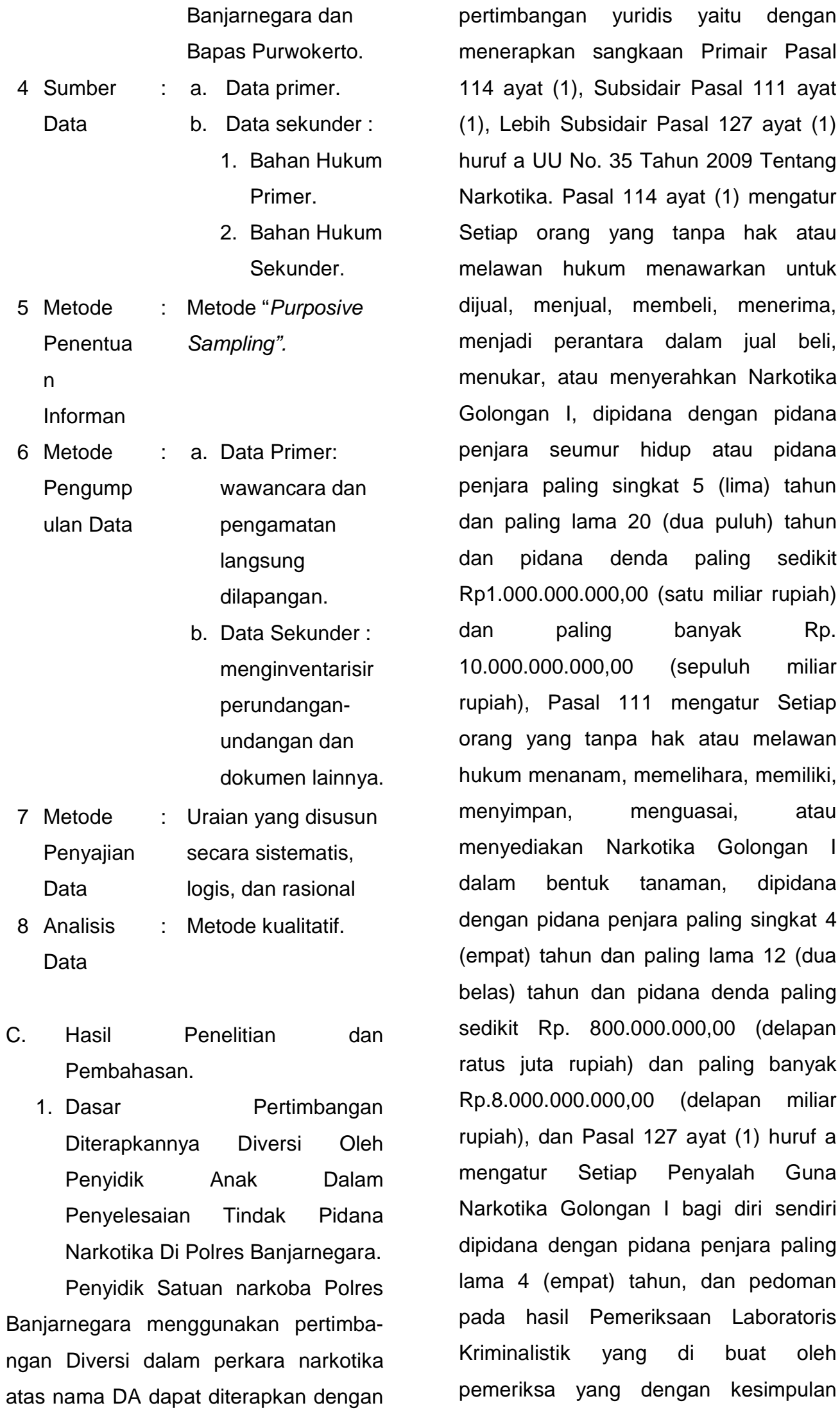


yaitu berupa BB - 1459/2015/NNF berupa ranting, daun dan biji tersebut diatas adalah Ganja terdaftar dalam Golongan I (satu) Nomor urut 8 (delapan) lampiran Undang-Undang Republik Indonesia Nomor 35 Tahun 2009 Tentang Narkotika dan BB1460/2015/NNF berupa urine milik Tersangka DA dan BB-1461/2015/NNF berupa urine milik Tersangka Adi Pratama Al Senti Al Setiv Bin Rizal tersebut diatas adalah mengandung Tetrahydocannobinol terdaftar dalam Golongan I (satu) Nomor urut 9 (sembilan) lampiran Undang-Undang Republik Indonesia Nomor 35 Tahun 2009 Tentang Narkotika.

Dalam kasus DA diterapkan sangkaan dalam bentuk Subsidaritas yaitu Primair Pasal 114 ayat (1) Subsidair Pasal 111 ayat (1) Lebih Subsidair Pasal 127 ayat (1) huruf a dengan mempertimbangkan pada hasil Pemeriksaan Laboratoris Kriminalistik yang di buat oleh pemeriksa yang bernama AKBP Ir. Sapto Sri Suhartomo, Kompol Ibnu Sutarto, Penata Eko Fery Prasetyo, S.Si yang diketahui oleh Kepala Laboratorium Forensik Cabang Semarang bernama Kombes Setija Dwiastuti, SKM, M.Kes dengan kesimpulan yaitu BB - 1459/2015/NNF berupa ranting, daun dan biji tersebut diatas adalah Ganja terdaftar dalam Golongan I (satu) Nomor urut 8 (delapan) lampiran Undang-Undang Republik Indonesia Nomor 35 Tahun 2009 Tentang Narkotika dan BB1460/2015/NNF berupa urine milik
Tersangka DA dan BB-1461/2015/NNF berupa urine milik Tersangka Adi Pratama Al Senti Al Setiv Bin Rizal tersebut diatas adalah mengandung Tetrahydocannobinol terdaftar dalam Golongan I (satu) Nomor urut 9 (sembilan) lampiran Undang-Undang Republik Indonesia Nomor 35 Tahun 2009 Tentang Narkotika, sehingga dalam penyelesaiannya penyidik berpedoman dengan Perma Nomor 4 tahun 2014 tentang Pedoman Pelaksanaan Diversi dalam Sistem Peradilan Pidana Anak tidak berpedoman pada Peraturan Pemerintah Nomor 65 Tahun 2015 dikarenakan pada waktu perkara ini ada belum diterbitkan oleh pemerintah.

Selanjutnya dalam mempertimbangkan Diversi harus mempertimbangkan litmas dari Bapas Purwokerto sebagaimana ketentuan Pasal 10 yang menyebutkan bahwa Kesepakatan Diversi untuk menyelesaikan tindak pidana yang berupa pelanggaran, tindak pidana ringan, tindak pidana tanpa korban, atau nilai kerugian korban tidak lebih dari nilai upah minimum provinsi setempat sebagaimana dimaksud dalam Pasal 9 ayat (2) dapat dilakukan oleh penyidik bersama pelaku dan/atau keluarganya, Pembimbing Kemasyarakatan, serta dapat melibatkan tokoh masyarakat serta Kesepakatan Diversi dilakukan oleh Penyidik atas rekomendasi Pembimbing Kemasyarakatan dapat berbentuk pengembalian kerugian dalam hal ada korban, rehabilitasi medis 
453 | J urnal Idea Hukum

Vol. 2 No. 2 Oktober 2016

Magister Hukum Fakultas Hukum Universitas J enderal Soedirman

dan psikososial, penyerahan kembali kepada orang tua/Wali, keikutsertaan dalam pendidikan atau pelatihan di lembaga pendidikan atau LPKS paling lama 3 (tiga) bulan atau pelayanan masyarakat paling lama 3 (tiga) bulan.

Penyelesaian perkara tindak pidana yang dilakukan oleh anak penyidik dapat menyelesaikan perkara tersebut dengan tidak mengikuti sistem peradilan pidana formal, akan tetapi Penyidik melalui kewenangannya sebagaimana diatur dalam Undang-Undang Nomor 2 Tahun 2002 Tentang Kepolisian Negara Republik Indonesia dapat menyelesaikan dengan memakai kewenangannya sebagaimana disebutkan dalam Pasal 18 UndangUndang Nomor 2 Tahun 2002 Tentang Kepolisian Negara Republik Indonesia. Kewenangan yang demikian disebut sebagai diskresi. Dengan kata lain sesuai kewenanganya yang dimiliki oleh aparat kepolisian dalam penyelesaian perkara yang melibatkan anak sebagai pelaku tindak pidana dapat menempuh penyelesaian diluar pengadilan salah satunya yang diamanatkan oleh Undang-Undang adalah melalui Diversi dan diamanatkan dalam Standart Minimum Rules for the Administration of Juvenile Justice (SMR-JJ) atau Beijing Rule dimana penting adanya jaminan bagi aparat penegak hukum untuk mengambil tindakan-tindakan kebijaksanaan dalam menyelesaikan perkara yang melibatkan anak dengan tidak mengambil jalan formal seperti menghentikan atau tidak meneruskan melalui proses peradilan pidana atau menyerahkan kepada masyarakat atau orang tua dan bentuk-bentuk kegiatan sosial lainnya. ${ }^{6}$

Menurut pendapat Nurnaingsih Amriani yang dimuat dalam Varia Peradilan yang menyatakan hal ini yang disebut sebagai Diskresi yang merupakan lampu hijau untuk penerapan Diversi sebagai upaya perlindungan terhadap anak. ${ }^{7}$ Berdasarkan hal tersebut di atas maka ada keterkaitan Diversi dengan diskresi di perkara ini dapat dibuktikan antara lainnya dari lahirnya kewenangan Diversi oleh Penyidik yang berasal dari kewenangan diskresi sebagaimana diatur dalam Undang-Undang No. 2 Tahun 2002 tentang Kepolisian Negara Republik Indonesia yaitu Pasal 18 ayat (1) bahwa untuk kepentingan umum pejabat kepolisian Negara Republik Indonesia dalam melaksanakan tugas dan wewenangnya dapat bertindak menurut penilaiannya sendiri. ${ }^{8}$

Diversi yang dilakukan oleh aparat penegak hukum didasarkan pada kewenangan diskresi yang dimiliki berdasarkan Undang-Undang Nomor 2 Tahun 2002 tersebut, sehingga Diversi merupakan tindakan yang sah dalam

6 Kusno Adi, 2009, Diversi Sebagai Upaya Alternatif Penanggulangan Tindak Pidana Narkotika oleh Anak, UMM press, Cetakan Pertama, hal. 117.

7 Nurnaningsih Amriani, 2012, Penanganan Perkara Anak Melalui Konsep Diversi Dan Restorative J ustice, Varia Peradilan, artikel, Ikahi, Jakarta, hal. 74.

8 Sri Sutatiek, 2012, Konkretisasi Pendekat Keadilan Restoratif (Restorative Justice) Melalui Diversi Oleh Hakim Anak Di Pengadilan Negeri, artikel, Varia Peradilan, Ikahi, Jakarta, hal. 54. 
Negara hukum Indonesia. Diversi yang dilakukan oleh aparat penegak hukum terutama penyidik dalam perkara narkotika merupakan tindakan yang sah karena diatur dalam Undang-undang Nomor 11 Tahun 2012 Tentang Sistem Peradilan Pidana Anak walapun pada waktu perkara narkotika atas DA belum ada Peraturan pelaksanaan UU SPPA tersebut, demi keadilan dan kemanfaatan bagi si pelaku maka dilakukan diversi dengan berdasarkan pertimbangan sesuai dengan Pasal 7 Undang-undang Nomor 11 Tahun 2012 Tentang Sistem Peradilan Pidana Anak dan penyidik juga berpedoman pada Perma Nomor 4 Tahun 2014 Tentang Pedoman Pelaksanaan Diversi dalam Sistem Peradilan Pidana Anak serta didasarkan pada kewenangan diskresi sebagaimana disebutkan dalam Undang-undang Nomor 2 Tahun 2002 Tentang Kepolisian Negara Republik Indonesia Pasal 18. Dari uraian tersebut diatas mengenai pertimbangan penyidik anak dalam Diversi atas nama DA dalam perkara penyalahgunaan narkotika menunjukkan peranan Kepolisian Polres Banjarnegara dalam melakukan Diversi sudah berjalan efektif dengan beberapa pertimbangan sebagaimana disebutkan diatas walaupun sebenarnya belum ada aturan pedoman pelaksanaan, tata cara diversi sebagaimana disebutkan dalam Pasal 15 Undang-Undang Nomor 11 Tahun 2012 tentang Sistem Peradilan Pidana Anak. Namun diversi yang dilakukan oleh Penyidik Menurut Penulis diversi ini dapat dibenarkan demi keadilan dan kemanfaatan yang terbaik bagi anak itu sendiri.

2. Proses Pelaksanaan Diversi Oleh Penyidik Anak Dalam Penyelesaian Tindak Pidana Narkotika Di Polres Banjarnegara.

Diversi pada hakikatnya mempunyai tujuan agar anak terhindar dari dampak negatif penerapan pidana. ${ }^{9}$ Proses pelaksanaan diversi perkara narkotika tersebut dapat disimpulkan dari hasil wawancara dan penelitian dokumen-dokumen yang berhubungan dengan perkara atas nama DA yang penulis lakukan, dapat dideskripsikan dalam alur bagan dan penjelasannya sebagai berikut :

$$
\begin{gathered}
\text { Bagan } \\
\text { Proses Pelaksanaan }
\end{gathered}
$$

Diversi atas nama DA dalam perkara narkotika

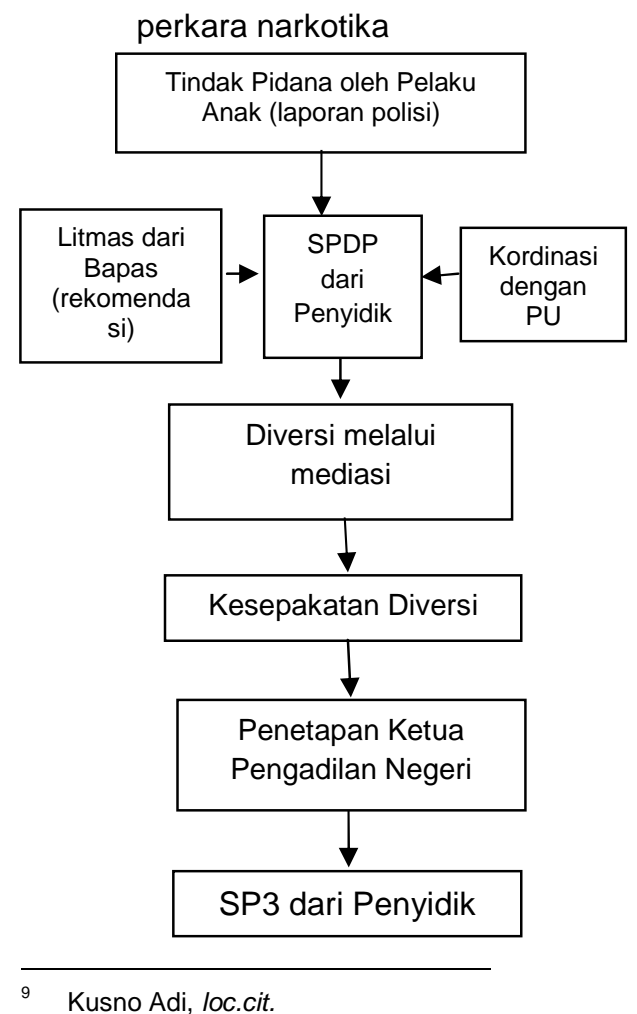




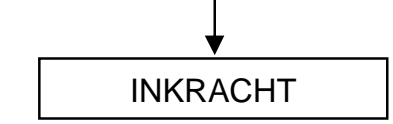

Melihat bagan diatas, dalam

proses penyidikan perkara anak atas nama DA karena tersangkut perkara narkotika berdasarkan Laporan Polisi No. Pol : LP/A/70/2015/JATENG/RES BNA, Surat Perintah Tugas No.Pol : SPRINGAS/02/VI/2015/Sat Resnarkoba tertanggal 8 Juni 2015, Surat Panangkapan No. Pol : Sp.Kap/02/VI/2015 tertanggal 8 Juni 2015, Surat Perintah Dimulainya Penyidikan, disemua surat tersebut mencantumkan mengenai dugaan atau sangkaan terhadap Tersangka DA yaitu telah terjadi dugaan tindak hak melawan hukum menawarkan untuk dijual, menjual, membeli, menerima, menjadi perantara dalam jual beli, menukar, menyerahkan narkotika golongan I atau tanpa hak melawan hukum memiliki, menyimpan, menguasai atau menyediakan narkotika golongan I dalam bentuk tanaman dan atau penyalah guna narkotika golongan I bagi diri sendiri, sebagaimana dimaksud dalam Primair Pasal 114 ayat (1) Subsidair Pasal 111 ayat (1) lebih Subsidair Pasal 127 ayat (1) huruf a Undang-Undang RI No. 35 Tahun 2009 Tentang Narkotika.

Selanjuntya, sebelum Diversi dilakukan harus ada SPDP terlebih dahulu dan pasal yang dikenakan pada anak DA, dan setelah berkordinasi dengan Penuntut Umum, Pasal yang dikenakan yaitu Primair Pasal 114 ayat
(1) subsidiaritas Pasal 111 ayat (1), Lebih Subsidiaritas Pasal 127 Ayat (1) huruf a Undang-Undang Nomor 35 Tahun 2009 dan dibuatkan Berita Acara Pemeriksaan atas nama DA dan Penyidik berkesimpulan akan dilakukan Diversi setelah mempertimbangkan kategori tindak pidana, umur anak, hasil penelitian kemasyarakatan dari Bapas dan dukungan lingkungan keluarga dan masyarakat (pasal 9), dalam perkara narkotika atas nama DA tidak perlu mendapat persetujuan dari korban karena perkara narkotika ini yang menjadi korban adalah DA sendiri sesuai dengan ketentuan Pasal 9 ayat (2) yaitu Kesepakatan Diversi harus mendapatkan persetujuan korban dan/atau keluarga Anak Korban serta kesediaan Anak dan keluarganya, kecuali untuk tindak pidana yang berupa pelanggaran, tindak pidana ringan, tindak pidana tanpa korban atau, nilai kerugian korban tidak lebih dari nilai upah minimum provinsi setempat, maka dapat dilakukan oleh penyidik bersama pelaku dan/atau keluarganya, Pembimbing Kemasyarakatan, serta dapat melibatkan tokoh masyarakat, setelah itu harus ada pertimbangan/ rekomendasi dari Bapas yang pada pokoknya untuk perkara atas nama DA harus dilakukan Diversi karena ada salah satu ancaman dibawah 7 (tujuh) tahun, kemudian penyidik mulai melakukan musyawarah Diversi dengan mediasi dengan mengundang para pihak yaitu DA dan orang tua, tokoh masyarakat Desa Kubang, petugas 
profesional kemasyarakat dalam hal ini dihadiri petugas dari P2TP2A, advokat, Bapas Purwokerto, mediasi dilaksanakan diruang Sat Resnarkoba Polres Banjarnegara pada tanggal 16 Juni 2015, dalam mediasi tersebut dihadiri oleh Sukendro dari Bapas Purwokerto, Ahmad Wahyono, M. Munir dari Dsn Jombalang desa kubang (tokoh masyarakat), Abdul Majid Kepala Desa Kubang, (tokoh masyarakat), Marmin, petugas P2TP2A Banjarnegara (pekerja Sosial), Kristiarso (advokad) dan Suparman (orang tua DA), DA sendiri, sebagai fasilitator adalah penyidik sat narkoba Polres Banjarnegara. Dari mediasi tersebut telah berhasil menghasilkan kesepakatan antara orang tua dan DA serta disaksikan yang hadir. Kemudian setelah terjadi kesepakatan dalam mediasi ini dan dibuatkan Berita Acara Diversi serta Kesepakatan Diversi, maka Diversi dianggap berhasil, kemudian Penyidik melaporkan kepada atasan langsung yaitu Kepala Polres Banjarnegara untuk mengirimkan Berita Acara Diversi dan Kesepakatan Diversi kepada Ketua Pengadilan Negeri untuk dibuatkan Penetapan Diversi, kemudian setelah menerima penetapan Diversi dari Ketua Pengadilan Negeri, Penyidik kemudian menerbitkan surat penghentian perkara atas nama DA sebagaimana tertuang dalam surat ketetapan No. Pol: S.TAP/01/VIII/2015/Resnarkoba tertanggal 1 Agustus 2015 dan memberitahukan kepada Penuntut Umum tentang pemberhentian perkara atas nama DA dengan Nomor Surat B/02.a/VIII/2015/Resnarkoba dan berdasarkan surat itu penyidik meminta pengembalian SPDP dari Penuntut Umum sehingga perkara dinyatakan mempunyai kekuatan hukum tetap.

Berdasarkan hasil wawancara dengan Jaksa pada Kejaksaan Negeri Banjarnegara mengenai Diversi, kesepakatan Diversi, penetapan Ketua Pengadilan Negeri, SP3, SPDP dapat dideskripsikan mengenai Diversi yaitu dalam perkara atas nama DA telah ada tembusan SPDP dan setelah dilakukan koordinasi maka dilakukan Diversi kemudian, ada kesepakatan Diversi yang dibuat oleh para pihak dan sudah dilaksanakan dan sudah mendapatkan penetapan dari Ketua Pengadilan Negeri maka penyidik mengeluarkan SP3 dan SP3 berserta kesepakatan dan penetapan Ketua Pengadilan Negeri tersebut dikirimkan kepada Kejaksaan Negeri, kemudian dengan adanya SP 3 tersebut maka ini menjadi dasar bagi Penuntut Umum untuk mengembalikan SPDP atas nama Tersangka DA tersebut.

Berdasarkan uraian tersebut di atas, maka dapat diperoleh gambaran bahwa proses pelaksanaan, pengawas an Diversi sampai perkara telah mempunyai kekuatan hukum tetap yang dilakukan oleh Penyidik Anak Polres Banjarnegara dalam perkara penyalah gunaan narkotika atas nama DA telah sesuai dengan ketentuan perundangundangan, sehingga dapatlah dikatakan bahwa pelaksanaan Diversi oleh 
457 | J urnal Idea Hukum

Vol. 2 No. 2 Oktober 2016

Magister Hukum Fakultas Hukum Universitas J enderal Soedirman

penyidik anak berjalan efektif. Efektivitas

hukum dibutuhkan kekuatan fisik untuk menegakkan kaidah-kaidah hukum tersebut menjadi kenyataan, berdasarkan wewenang yang sah. ${ }^{10}$ Dalam hal ini Penyidik anak telah menggunakan kaidah-kaidan hukum dalam Undang-Undang Nomor 11 Tahun 2012 tentang sistem peradilan pidna anak dan Perma Nomor 4 Tahun 2014 Tentang Pedoman Pelaksanaan Diversi dalam Sistem Peradilan Pidana Anak.

3. Hambatan-Hambatan Dalam

Pelaksanaan Diversi Oleh Penyidik

Anak Dalam Penyelesaian Tindak

Pidana Narkotika Di Polres

Banjarnegara

Dari hasil penelitian yang penulis lakukan didapat data mengenai hambatan-hambatan dalam proses Diversi oleh penyidik anak yaitu hambatan atau kendala dari penyidik dalam proses Diversi perkara atas nama DA tersebut ketika mengumpulkan para pihak, lamanya waktu untuk sepakat dan adanya kecurigaan dari sebagian warga, serta belum adanya pedoman (SOP) dari pimpinan Polri dalam hal Diversi sehingga penyidik hanya beracuan pada UU SPPA dan Perma dari Mahkamah Agung, karena Peraturan Pemerintah tentang Diversi belum ada. Peraturan Pemerintah Republik Indonesia Nomor 65 Tahun 2015 Tentang Pedoman Pelaksanaan

10 Subarso, Siswantoro, 2011, Penegakan Hukum Psikotropika Dalam Kajian Sosiologi Hukum, Ed.1-4, Rajawali, Jakarta, hal. 89.
Diversi dan Penanganan Anak Yang Belum Berusia 12 (dua belas) tahun ada setelah perkara atas nama DA mempunyai kekuatan hukum tetap.

Ketentuan dalam Peraturan Pemerintah Republik Indonesia Nomor 65 Tahun 2015 Tentang Pedoman Pelaksanaan Diversi dan Penanganan Anak Yang Belum Berusia 12 (dua belas) tahun dikeluarkan oleh Pemerintah sesuai amanat dari Pasal 15 Undang-Undang Nomor 11 Tahun 2012 Tentang Sistem Peradilan Pidana Anak yang mengatur tentang Ketentuan mengenai pedoman pelaksanaan proses Diversi, tata cara dan koordinasi pelaksanaan Diversi diatur dengan Peraturan pemerintah. Peraturan Pemerintah Republik Indonesia Nomor 65 Tahun 2015 Tentang Pedoman Pelaksanaan Diversi dan Penanganan Anak Yang Belum Berusia 12 (dua belas) tahun mengatur ketentuan tentang Diversi tanpa korban ditingkat penyidik diatur dalam Pasal 26 sampai dengan Pasal 30.

D. Penutup
A. Simpulan.

Dari hasil penelitian dapat diambil suatu simpulan sebagai berikut :

1. Dasar pertimbangan diterapkannya diversi oleh Penyidik Anak dalam penyelesaian tindak pidana narkotika di Polres Banjarnegara berdasarkan ketentuan sebagai berikut :

a. Adanya ketentuan Pasal 7 ayat (2) Undang-Undang Nomor 11 Tahun 2012 Tentang Sistem 
Peradilan Pidana Anak dan

Pasal 3 Perma Nomor 4 Tahun

2014 Tentang Pedoman

Pelaksanaan Diversi Dalam

Sistem Peradilan Pidana Anak

dapat diterapkan diversi jika

tindak pidana yang diancam

dengan pidana penjara dibawah

7 (tujuh) dan bukan merupakan

suatu pengulangan tindak

pidana serta didakwa pula

dengan tindak pidana yang

diancam dengan pidana penjara

7 (tujuh) tahun atau lebih dalam

bentuk surat dakwaan subsidi-

aritas, alternatif, kumulatif mau

pun kombinasi (gabungan), ada

nya Rekomendasi dari Bapas

Purwokerto sebagaimana keten-

tuan Pasal 10 Undang-Undang

Nomor 11 Tahun 2012 Tentang

Sistem Peradilan Pidana Anak, adanya kewenangan diskresi

dari Kepolisian sebagaimana

ketentuan Pasal 18 ayat (1)

Undang-Undang Nomor 2

Tahun 2002 tentang Kepolisian

Negara Republik Indonesia.

b. Diversi dalam perkara narkotika atas nama DA dilakukan tanpa adanya kesediaan dari korban karena dalam perkara narkotika, Pelaku termasuk juga korban jadi merupakan pengecualian dari diversi pada umumnya yang mengharuskan ada persetujuan dari korban sebagaimana ketentuan Pasal 10 UndangUndang Nomor 11 Tahun 2012
Tentang Sistem Peradilan

Pidana Anak,

2. Proses Pelaksanaan diversi oleh Penyidik Anak dalam penyelesaian tindak pidana narkotika di Polres Banjarnegara sebagai berikut:

a. Pelaksanaan diversi dilakukan oleh penyidik bersama pelaku/ korban dan atau keluarganya, pembimbing kemasyarakatan, serta melibatkan tokoh masyara kat, Pelaksanaan diversi dilakukan dengan musyawarah atau mediasi yang menghasil kan kesepakatan diversi antara DA dan orang tuanya, dimana DA dikembalikan kepada orang tuanya, kemudian Berita Acara dan Kesepakatan Diversi oleh Penyidik dikirimkan ke Pengadil an Negeri untuk dibuatkan Penetapan diversi, oleh Pengadi lan Negeri kemudian dibuatkan Penetapan Diversi No. 2/Pid.Sus.Anak/2015/PN Bnr tertanggal 24 Juni 2015., setelah Penyidik menerima Penetapan dari Ketua Pengadil an Negeri dan Kesepakatan diversi telah dilaksanakan oleh para pihak maka Penyidik mengeluarkan Surat Perintah Penghentian Penyidikan Nomor Pol: SP.Sidik/02.a/VIII/2015/Res Narkoba tertanggal 01 Agustus 2015 atas nama DA.

b. Setelah Penyidik mengeluarkan Surat Perintah Penghentian Penyidikan Nomor Pol : 
459 | J urnal Idea Hukum

Vol. 2 No. 2 Oktober 2016

Magister Hukum Fakultas Hukum Universitas J enderal Soedirman

SP.Sidik/02.a/VIII/2015/Res

Narkoba tertanggal 01 Agustus 2015 atas nama DA, maka

Berita Acara, Kesepakatan

Diversi serta Penetapan Ketua

Pengadilan Negeri ditembuskan

kepada Penuntut Umum

sebagai dasar bagi Penuntut

Umum untuk mengembalikan

SPDP atas nama DA, sehingga

perkara tersebut menjadi

inkracht.

3. Hambatan-Hambatan Dalam

Pelaksanaan Diversi Oleh Penyidik

Anak Dalam Penyelesaian Tindak

Pidana Narkotika Di Polres

Banjarnegara ada beberapa faktor yaitu :

a. Faktor Subtansi Hukum yaitu belum adanya Peraturan pelaksanaan dari UndangUndang Nomor 11 tahun 2012 tentang Sistem Peradilan

Pidana Anak terutama mengenai Diversi, belum adanya SOP bagi kepolisian mengenai diversi bagi perkara narkotika sebagaimana amanat dari Undang-Undang Nomor 11 Tahun 2012 Tentang Sistem Peradilan Pidana Anak

b. Faktor budaya hukum yaitu ketika mengumpulkan para pihak, lamanya waktu untuk sepakat dan adanya kecurigaan dari sebagian warga, dan belum pahamnya warga masyarakat mengenai Diversi sehinga perlu adanya sosialisasi mengenai diversi dalam Undang -Undang Nomor 11 Tahun 2012 Tentang Sistem Peradilan Pidana Anak.

B. Saran

1. Perlu adanya SOP bagi kepolisian mengenai diversi bagi perkara narkotika sebagaimana amanat dari Undang-Undang Nomor 11 Tahun 2012 Tentang Sistem Peradilan Pidana Anak.

2. Perlu adanya Sosialisasi mengenai Undang-Undang Nomor 11 Tahun 2012 Tentang Sistem Peradilan Pidana Anak termasuk upaya diversi dalam perkara narkotika.

3. Perlunya dilakukan Assement terhadap Pelaku tindak pidana narkotika.

4. Perlunya dilakukan rehabilitasi terhadap pelaku penyalahgunaan tindak pidana narkotika bagi diri sendiri.

\section{DAFTAR PUSTAKA}

Achmad Ali, 2002, Keterpurukan Hukum di Indonesia, Ghalia Indonesia, Jakarta.

Apong Herlina, dkk, 2004, Perlindungan terhadap anak yang berhadapan dengan hukum, Manual Pelatihan untuk Polisi, Jakarta, POLRIUNICEF.

Anthon Susanto,2004, Wajah Peradilan Kita, Refika Aditama, Bandung.

Barda Nawawi Arief, 2012, Mediasi Penal : Penyelesaian Perkara Pidana Di Luar Pengadilan, Pustaka Magister, Semarang.

Penerbit Universitas Diponegoro.

Bambang Sunggono, 2015, Metodologi Penelitian Hukum, Ed.1, Cetakan ke-15, PT Rajawali, Jakarta.

Dwija Priyanto, 2007, Pemidanaan untuk Anak Dalam Konsep 
Rancangan KUHP (Dalam Kerangka Restorative Justice), Lambaga Advokasi Hak Anak (LAHA), Edisi VIII/Volume III, Bandung.

Faisal, 2010, Menerobos Positivisme Hukum, Rangkang Education, Yogyakarta.

Gunawan T.J., 2015, Konsep Pemidanaan Berbasis Nilai Kerugian Ekonomi, Genta Press, Yogyakarta.

Koesno Adi, 2015, Diversi Tindak Pidana Narkotika Anak, PT Setara Pres, Malang.

Mardjono Reksodiputro, 1993, "Sistem Peradilan Pidana Indonesia (Melihat kepada kejahatan dan penegakan hukum dalam batasbatas toleransi),"Pidato Pengukuhan Penerimaan Jabatan Guru Besar Tetap Dalam IImu Hukum Pada Fakultas Hukum Universitas Indonesia, Jakarta, hal. 1.

M. Ali Zaidan, 2015, Menuju Pembaharuan Hukum Pidana, Sinar Grafika, Jakarta.

Marwan Effendy, 2014, Teori Hukum dari Perspektif Kebijakan, Perbandingan dan Harmonisasi Hukum Pidana, Gaung Persada Press Group, Jakarta.

Marlina, 2009, Peradilan Pidana Anak di Indonesia : Pengembangan Konsep Diversi dan Restorative Justice, PT Refika Aditama, Bandung.

Natangsa Subakti, 2015, Peradilan Restoratif Dalam Bingkai Empiri, Teori dan Kebijakan, Genta Publising, Yogyakarta.

Nur Dewata , Mukti Fajar dan Yulianto Achmad. 2010. Dualisme Penelitian Hukum Normatif dan Empiris. Yogyakarta: Pustaka

Rocky Marbun, 2015, Sistem Peradilan Pidana Indoensia, Suatu Pengantar, Malang, Setara Pres.

Setya Wahyudi, 2011, Implementasi Ide Diversi Dalam Pembaharuan Sistem Peradilan Pidana Anak di Indonesia, Genta Publising, Yogyakarta. , 2009, Diversi Dalam Sistem Peradilan Pidana Anak, Badan Penerbit Universitas Diponegoro, Semarang.
Soerjono Soekanto, 2014, Faktor-faktor yang mempengaruhi Penegakan Hukum, PT Raja Grafindo Persada, Ed.1-Cet.13, Jakarta.

Siswantoro Subarso, 2011, Penegakan Hukum Psikotropika Dalam Kajian Sosiologi Hukum, Ed-1-4, PT Rajawali, Jakarta.

Sianturi S, 1996, Asas-Asas Hukum Pidana di Indonesia dan Penerapnnya, Alumni Ahaem, Jakarta.

Widodo, 2015, Problematika Pembinaan Anak Pelaku Tindak Pidana Dalam Perspektif Hukum Pidana, Aswaja Pressindo, Yogyakarta.

Willian B Chambliss dan Robert B Siedman, 1971, Law Order and Power, Reading Mass: AddisonWesley.

Keadilan Restoratif Sebagai Tujuan Pelaksanaan Diversi Pada Sistem Peradilan Pidana Anak, Dr. Ridwan Mansyur, SH., MH, https://www.mahkamahagung.go.i d/ diakses pada hari Senin, 27 September 2015.

Penerapan Diversi dan Restorative Justice dalam Sistem Peradilan Pidana Anak, http://jabar.kemenkumham.go.id/p usat-informasi/artikel/965penerapan-diversi-danrestorative-justice-dalam-sistemperadilan-pidana-anak, diakses pada 5 Oktober 2015, jam 08.30 WIB. 